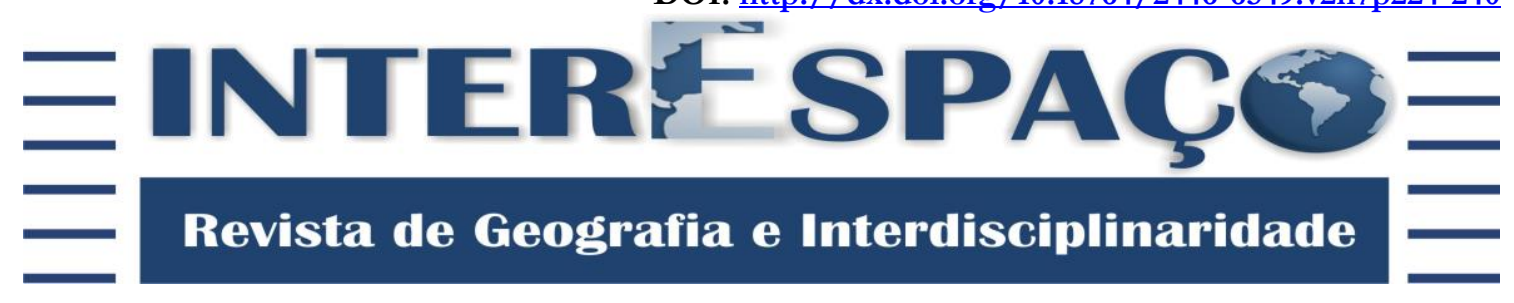

\title{
O CONFLITO COMO PROMOTOR DA LIBERDADE NA REPÚBLICA MAQUIAVELIANA
}

\author{
Luis Fernando de Carvalho Sousa \\ Mestrando em Filosofia pela Universidade Estadual do Oeste do Paraná - UNIOESTE. \\ luisffilo@hotmail.com
}

\begin{abstract}
RESUMO
O pensamento maquiaveliano é motivo de disputas e controvérsias entre diversos pesquisadores. Esses embates, geralmente, giram em torno das interpretações de posições políticas e implicações de conceitos utilizados pelo autor. O presente artigo buscou compreender a questão do conflito na república maquiaveliana e seus atores, visando apontar o papel do povo no conflito e a função que Maquiavel lhe atribui como um dos principais agentes na manutenção em promoção da liberdade dentro do regime republicano proposto pelo filósofo. Tal elemento aparece como um dos principais agentes na manutenção e promoção do regime democrático. Nesse sentido, tornam-se elementos fundamentais para se entender as disputas políticas na república. Por meio de uma pesquisa bibliográfica o artigo buscou compreender essa relação conflituosa que se dá dentro do ambiente republicano e concluiu que embora havendo divergências em torno das disposições dentro da república o papel de solucioná-las cabe sempre às instituições.
\end{abstract}

Palavras-chave: Maquiavel; Conflito; Liberdade; República; Povo.

\section{THE CONFLICT AS A PROMOTER OF FREEDOM IN THE MACHIAVELLIAN REPUBLIC}

\begin{abstract}
The Machiavellian thinking is cause of disputes and controversies between several researchers. These conflicts usually revolve around the interpretation of political positions and implications of concepts used by the author. This article seeks to understand the issue of conflict in the Machiavellian republic and its actors, aiming to identify the role of the people in the conflict and the role that Machiavelli attributes to it as one of the key players in maintaining in promoting freedom within the republican regime proposed by the philosopher. This element appears as one of the key players in the maintenance and promotion of democracy. In this sense, become key elements to understand the political disputes in the republic. Through a bibliographical research the article sought to understand this conflicting relationship that takes place within the republican environment and concluded that although there are divergences around the dispositions within the republic the role of resolving them always rests with the institutions.
\end{abstract}

Keywords: Machiavelli; Conflict; Freedom; Republic; People.

\section{EL CONFLICTO COMO UN PROMOTOR DE LA LIBERTAD EN LA REPÚBLICA MAQUIAVÉLIANA}


El pensamiento maquiavélico es causa de conflictos y controversias entre varios investigadores. Estos conflictos por lo general giran en torno a la interpretación de las posiciones políticas e implicaciones de los conceptos utilizados por el autor. En este artículo se busca entender el tema del conflicto en la república maquiavélica y sus actores, con el objetivo de identificar el papel del pueblo en los conflictos y el papel que Maquiavelo atribuye a él como uno de los jugadores clave en el mantenimiento en la promoción de la libertad dentro del régimen republicano propuesto por el filósofo. Este elemento aparece como uno de los jugadores clave en el mantenimiento y promoción de la democracia. En este sentido, se convierten en elementos clave para entender los conflictos políticos en la república. A través de un artículo de revisión de la literatura tuvo como objetivo comprender esta relación de confrontación que tiene lugar dentro del entorno republicano y concluyó que, aunque existe desacuerdo sobre las disposiciones en función de la república para resolverlos siempre recae en las instituciones.

Palabras clave: Maquiavelo; El Conflicto; La Libertad; La República; Pueblo.

\section{INTRODUÇÃO}

A noção república a partir do pensamento de Maquiavel é imprescindível para a compreensão moderna de política pelo fato de ser o pensador italiano o primeiro a atribuir uma função proeminente ao povo, impingindo-lhe um papel ativo no processo de luta pela democracia e pelos embates entre os grupos que compõem o ambiente republicano. Nisto o pensador florentino de coloca com um pensador moderno, pois entende a disputa política com dois grupos oposto e ativos no processo (MCCORMICK, 2013).

Não é, contudo, consenso que o papel do povo é de resistência ativa. Nesse sentido as interpretações em torno da obra de Maquiavel é centro de diversas disputas entre pensadores políticos. No caso da república maquiaveliana, há posições defendidas por Quentin Skinner (2009), por exemplo, que diferem frontalmente de outros intérpretes, como Jonh McCormick (2013). Essas divergências dão-se em torno de diversas posições e conceitos, sobretudo, os ligados à concepção da atuação no espaço republicano. Em alguns momentos deste trabalho, essas concepções serão confrontadas num esforço de melhor captar o pensamento de Maquiavel. Não é nossa intenção discorrer sobre as várias interpretações do pensamento maquiaveliano, mas faz-se necessária essa pontuação para que os conceitos sejam mais bem elucidados.

Este trabalho visou tratar do conflito como causa da liberdade republicana. Para isso, foram pontuados alguns elementos característicos do ideal de república em Maquiavel e, de forma sucinta, foi abordado o espaço republicano como aberto às representações populares distintas. Em seguida, abordamos o conflito entre os humores componentes da vida política; buscamos a fundamentação do pensamento maquiaveliano que legitima o conflito como promotor da liberdade na república e, para isso, recorremos aos textos 
clássicos do autor e às análises de comentadores que interpretam as teorias do pensador italiano. Por fim, analisamos o papel do povo como elemento ativo no processo político em Maquiavel. Neste item, buscamos compreender o motivo pelo qual o filósofo aponta para a ação do povo como uma das mais importantes, tanto no equilíbrio quanto na manutenção da liberdade republicana.

\section{A REPÚBLICA MAQUIAVELIANA: liberdade participativa}

Os estudos sobre o pensamento maquiaveliano sofreram profundas transformações, sobretudo, após a segunda metade do século XX, quando o pensador florentino foi, paulatinamente, deixando de ser visto como o "conselheiro dos tiranos" e passou a ser visto como o "filósofo da liberdade". Isso, graças aos estudos de autores como John McCormick e Hans Baron, que resgataram o caráter republicano de Maquiavel e sua contribuição para o debate das democracias contemporâneas. Para McCormick (2013), por exemplo, mais do que uma ideia da república como império da lei, Maquiavel trata de uma "teoria da democracia", que pode ser pensada, inclusive, na superação de alguns obstáculos existentes nos sistemas de governo contemporâneos.

Em um ensaio sobre a república em Maquiavel, Ricardo Silva (2010) aborda os aspectos principais da obra do florentino e das considerações feitas a partir da leitura e interpretação de McCormick (que propõem uma interpretação alternativa à da escola de Cambridge, tendo em Quentin Skinner um de seus notáveis expoentes). Silva (2010, p. 49) destaca que a interpretação do pensamento maquiaveliano feita pela referida escola, além de compreender os aspectos sociológicos na obra de Maquiavel de forma distorcida, mal se compreenderam também "as implicações constitucionais da concepção maquiaveliana de liberdade".

A forma como os autores como Skinner compreendem Maquiavel sinaliza para uma interpretação equivocada do republicanismo, de forma a apontar para uma república aristocrática, posição essa que não coaduna com os postulados apresentados por Maquiavel em sua obra ${ }^{1}$. Silva apresenta um apontamento sobre a concepção da república segundo Maquiavel:

[...] Maquiavel é compatível com o ideal de uma república com intensa participação popular, uma república em que o ideal de civismo, aristocrático por

\footnotetext{
${ }^{1}$ A noção política de Maquiavel encontra-se, sobretudo, em: Discursos sobre a primeira década de Tito Lívio. São Paulo: Martins Fontes, 2007; O Príncipe. São Paulo: Martins Fontes, 2010 e História de Florença São Paulo: Musa, 1994. Tais obras trazem o desenvolvimento do pensamento sobre a noção de república.
} 
O conflito como promotor da liberdade na república maquiaveliana Luis Fernando de Carvalho Sousa

definição, não se sobreponha ao ideal do plebeísmo calcado na ideia de extensão da cidadania (SILVA, 2010, p. 50).

Depreende-se disso que a liberdade na república maquiaveliana consiste, então, em uma liberdade de participação política. Mais do que participação, Maquiavel aponta para o exercício da liberdade democrática como atitude cívica, ou seja, um valor que os cidadãos republicanos deveriam conservar como virtude. O que caracteriza basicamente essa liberdade republicana, de acordo com Adverse, é a convicção de que a liberdade individual não pode ser dissociada da liberdade do Estado, de modo que "a participação ativa dos cidadãos nos afazeres cívicos se torna uma exigência, assim como a organização institucional de um espaço em que o poder é exercido pelos membros da comunidade política" (ADVERSE, 2007, p. 34).

$\mathrm{Na}$ contramão de uma república aristocrática, defendida pela escola de Cambridge, Silva (2010) interpreta Maquiavel de acordo com os pressupostos de McCormick entendendo o pensador florentino como um defensor da república popular, incentivando, assim, a participação de todos os cidadãos, indistintamente.

\footnotetext{
A escolha por sorteio, envolvendo todos os cidadãos, servia como garantia de que as chances dos ricos de serem os escolhidos pela fortuna não seriam maiores do que sua participação percentual na cidadania, assegurando que a distribuição de cargos ocorreria aleatoriamente entre todas as classes de cidadãos. O mecanismo de sorteio, aliado ao "revezamento regular e frequente dos cargos oficiais", evitaria que os setores mais ricos pudessem usar seus recursos quer "para aninharem-se eles mesmos num cargo", quer "para influenciar ou determinar a nomeação de sucessores de opiniões semelhantes ou interesses similares" (SILVA, 2010, p. 52).
}

A república maquiaveliana é entendida, dessa maneira, como um espaço participativo, um local democrático. Todos os âmbitos da atividade política componentes da república, nesse sentido, necessitam ser contemplados, desde a participação, organização, passando pelas denúncias e direito de defesa. De acordo com Maquiavel, todos esses mecanismos necessitam ser ordenados e institucionalizados para que não haja corrupção. "Por isso, nada há que torne mais estável e firme uma república do que ordenála de tal modo que a alteração dos humores que a agitam encontre a via de desafogo ordenada pelas leis” (MAQUIAVEL, 2007, p. 33). 
Além de ser imprescindível a participação política na república, é necessário que seja regulada pelos humores ${ }^{2}$ e respeite as instituições estabelecidas de forma a não tender em nada para interesses particulares. Nesse sentido, o conflito, no seio republicano, é necessário para manter a liberdade e fazer que a vida democrática seja participativa e estimule a virtude cívica.

Silva (2010) estabelece um paralelo entre o republicanismo de Maquiavel e as democracias modernas e contemporâneas. Para ele,

[...] estas últimas procuram assegurar a responsividade de representantes e governantes de três diferentes formas: pela via do processo de punição e recompensa eleitoral; por meio do mecanismo institucional de separação e contraposição de poderes; e, em casos extremos, pela ameaça de remoção de elites políticas corrompidas, mediante processo de impeachment conduzido por membros da própria elite (SILVA, 2010, p. 51).

$\mathrm{Na}$ teoria maquiaveliana, esse modelo é perigoso, uma vez que não leva em conta os mecanismos institucionais conflitivos, respeitando a disposição dos humores componentes da república (a dos grandes de dominar e a do povo de não ser dominado) e tendendo mais para uma república aristocrática do que popular.

O ideal republicano de Maquiavel consiste na não dominação de um humor sobre outro, por isso, concebe um papel proeminente ao povo como guardião da liberdade, uma vez que, para manter seu humor, preservará e zelará pela sua plena satisfação em detrimento da dominação dos grandes. A ênfase dada ao povo, na obra maquiaveliana, rendeu conotações como "república popular" ao ideal teórico do florentino. Um dos entusiastas dessa interpretação é McCormick, que retrata Maquiavel como sendo este o defensor de um regime popular.

De acordo com o estudioso estadunidense McCormick, Maquiavel é um revolucionário pensador político pelo fato de colocar o povo como proeminente no processo democrático. Desde a Antiga Grécia até os postulados do pensador florentino, não se tinha pensado no povo como um dos elementos fundamentais de participação ativa no sistema político.

Os fundadores políticos e os filósofos políticos jamais atribuíram tal lugar às massas. Por 'povo', Maquiavel geralmente entende a plebe, isto é, os cidadãos romanos que não faziam parte da classe patrícia, excluídos os não cidadãos como as mulheres, os escravos e os residentes estrangeiros (MCCORMICK, 2013, p. 259).

\footnotetext{
${ }^{2}$ Por humor, Maquiavel entende a disposição dos distintos grupos componentes da vida política. Os humores tratados em sua obra Discursi sinalizam para o desejo do povo de não ser dominado, e dos grandes, de dominar (AMES, 2014).
} 
Esse caráter popular da república maquiaveliana permite que haja espaços para os embates políticos e a participação ativa dos cidadãos em todas as decisões. Maquiavel pressupõe um espaço democrático que contemple: a) a combinação de sorteios com os mecanismos eleitorais para a escolha de magistrados; b) a criação de instituições representativas dos cidadãos; c) a instituição de "julgamentos políticos", em que os juízes são todos os cidadãos (SILVA, 2010).

Indubitavelmente, Maquiavel foi defensor de um sistema democrático amplo e inclusivo, que, por meio da liberdade política, contempla as diferentes demandas sociais e as disposições representadas nesse âmbito. A analogia que faz da história romana visa sempre sinalizar para Florença com o intuito de comparar as realidades e legitimar determinadas ações, sobretudo, referentes ao povo. "Sua república patrocina a expressão da vontade popular nem sempre mediada por representantes ou restringida por procedimentos excludentes" (MCCORMICK, 2013, p. 270).

\section{O CONFLITO COMO ESSENCIAL NA VIDA REPUBLICANA}

Neste segundo momento, trataremos da questão do conflito como fator essencial na vida republicana a partir do trabalho Discursos sobre a primeira década de Tito Lívio (2007), em que Maquiavel trata da relação conflitiva entre os grupos políticos que compõem a república como fator preponderante para a liberdade republicana.

De acordo com Ames (2014), Maquiavel, ao analisar os discursos de Tito Lívio, traça paralelos entre Roma e Esparta - o que podemos chamar de análise comparativa -, refletindo a realidade de Florença e Veneza, respectivamente, num intuito de instruir e estimular a população florentina a uma participação republicana com o espírito cívico, baseado no bem comum e no amor à pátria.

É, sobretudo, no capítulo quatro dos Discursos que Maquiavel trata da questão do conflito e sua importância para a liberdade republicana:

Direi que quem condena os tumultos entre os nobres e a plebe parece censurar as coisas que foram a causa primeira da liberdade em Roma e considerar mais as assuadas e a grita de tais tumultos nasciam do que os bons efeitos que eles geravam; e não considerar que em toda república há dois humores diferentes, o do povo, e dos grandes, e que todas as leis que se fazem em favor da liberdade nascem da desunião deles [...](MAQUIAVEL, 2007, p. 21-22).

Nessa passagem, Maquiavel evidencia sua posição em relação ao conflito político dentro do espaço republicano e as disposições entre os grupos que compõem a república 
como salutares na manutenção da liberdade. Como se dá essa disputa? Qual é o papel das instituições? Quais as intenções que as devem nortear? Essas perguntas são inevitáveis quando se pensa no tema do conflito dentro da república maquiaveliana.

A disputa na república se dá em torno dos humores (umori) de cada grupo político: os grandes e o povo; o primeiro com o desejo de dominar, e o segundo com desejo de não ser dominado. Esses humores se opõem dentro da dinâmica republicana que Maquiavel compara à medicina galênica. Para o florentino "à semelhança dos humores que se misturam no corpo humano, segundo a medicina hipocrático-galênica, o corpo político também é agitado por 'humores" (AMES, 2014, p. 280). Os humores precisam estar equilibrados para que a vida republicana possa ser conservada de forma salutar, uma vez que eles representam a harmonia e o equilíbrio do corpo político. Se houver algum desajuste, necessita-se dar vazão por meio de mecanismos institucionais para que não haja supremacia de um grupo sobre o outro, o que acarretaria prejuízos à liberdade republicana.

Roma é o modelo de onde partem as argumentações maquiavelianas numa espécie de "arquétipo republicano". Suas relações políticas tipificam como equilibrar os conflitos existentes na república por meio de mecanismos institucionais. Um dos exemplos citados por Maquiavel é a criação dos tribunos como decorrência de um conflito envolvendo as duas forças antagônicas, plebe (povo) e a nobreza (grandes):

\footnotetext{
Por isso, depois de muitas confusões e tumultos e perigos de perturbações, surgidos entre a plebe e a nobreza, chegou-se à criação dos tribunos, para a segurança da plebe; e [os romanos] ordenaram tanta proeminência e reputação que a partir de então puderam ser sempre intermediários entre a plebe e o senado, obviando a insolência dos nobres (MAQUIAVEL, 2007, p. 21).
}

O pensador florentino salienta que os conflitos que movimentam a vida na república devem ocorrer de forma equilibrada, de maneira que não haja supremacia de um grupo político sobre outro, ou um desequilíbrio das forças componentes da república, prejudicando, assim, a liberdade republicana.

Embora o conflito seja essencial para a sobrevivência da república e salvaguarde os direitos dos grupos políticos, trata-se de um antagonismo de desejos. Tal relação expressa o pensamento maquiaveliano sobre a relação política na república:

\footnotetext{
Ao caracterizar o desejo dos grandes como um desejo de comandar e o do povo como de viver em liberdade, Maquiavel deixa claro que o que funda a relação política não se confunde nem com a regulação do desejo de poder (dos grandes), nem com a regulação do desejo de liberdade (do povo). O que funda a relação política é, pelo contrário, a diferença definitiva dos humores (AMES, 2009, p. 184).
} 
A disputa dos humores que se faz entre os grandes e o povo opõem os desejos de comandar e o de não ser comandado dando a tônica das relações políticas. Maquiavel faz uma análise dos conflitos existentes na Roma Antiga, focando Florença, buscando, com isso, traçar um paralelo entre as duas repúblicas. Nesse sentido, reconhece o papel do povo como sujeito político integrante do processo republicano, tendo-o como essencial para a sobrevivência do regime e manutenção da dinâmica política.

De acordo com Adverse (2007), esse ordenamento político na cidade passa a ser definido a partir da oposição entre os desejos que impulsionam seus cidadãos. $O$ autor faz duas considerações que entende como relevantes para tratar a temática do republicanismo maquiaveliano: uma em relação à natureza dos humores, e outra, ao efeito de seu confronto. No que diz respeito ao confronto, é mister observar que a liberdade à qual Maquiavel faz referência é o regime republicano e não o tirânico, ou outro regime. Quanto à natureza dos humores, "o que podemos apreender imediatamente é que o desejo dos grandes é positivo porque é determinado, ao passo que o desejo do povo, indeterminado, seria negativo: antes de mais nada, o povo exige apenas não ser oprimido" (ADVERSE, 2007, p. 36). Esse dualismo de desejos faz que o equilíbrio político seja mantido de maneira a garantir a dinâmica da vida política.

Uma vez entendido que, para a manutenção salutar na república, o conflito entre os grupos se faz necessário, resta saber qual é o papel das instituições no que diz respeito à manutenção e ao ordenamento dessa relação.

Adverse explica que há distinção entre disputar e combater as posições dentro do cenário republicano, pois a disputa "implica uma universalização na medida em que os adversários estão comprometidos com um mesmo conjunto de regras, logo, envolve algum grau de consenso; daí, a referência que faz Maquiavel à lei” (ADVERSE, 2007, p. 42). Tal referência diz respeito ao equilíbrio das disputas por meios institucionais do regime, equacionando os humores opostos, sempre no plano público, visando o bem comum. A distinção defendida pelo autor se dá pelo fato de que, no combate, os objetivos ocorrem em torno da particularidade, de maneira que os adversários se enfrentam em campos opostos, um lutando para sobrepujar o outro, não levando em conta as virtudes cívicas pautadas em interesses do bem público. Nesse sentido, a universalidade pressupõe, de acordo com o comentador maquiaveliano, a eliminação do outro, que, "para Maquiavel, é esse o mal que acomete Florença: aí a divisão origina 'seitas', impedindo o fortalecimento do tecido social e a formação de uma comunidade política verdadeiramente republicana" (ADVERSE, 2013, p. 43). 
Por esse motivo, faz-se necessária a presença das instituições na disputa (e não no combate) dos humores de forma a ordenar o conflito existente entre as forças antagônicas que compõem a república. Em sua interpretação sobre a república maquiaveliana, Ramos defende que "a república mais estável é aquela que consegue dar expressão institucional ao conflito de maneira pública a fim de evitar a facção, contrária à vida comum” (RAMOS, 2010, p. 45). Tem-se, nessa afirmação, mais um elemento para melhor se compreender a organização dos conflitos na vida republicana: a regulação institucional em favor do bem comum. Não basta apenas enfatizar a importância dos conflitos e identificar os grupos envolvidos, necessita-se pontuar que as instituições possuem um papel preponderante no favorecimento desses embates, regulando-os de forma a viabilizar a dinâmica da política republicana.

Nessa mesma linha de interpretação, corrobora Abreu (2013), salientando que o escopo do pensamento maquiaveliano serve tanto para valorizar o conflito quanto para propor um governo em que as diferenças possam ser contempladas, pois, "por meio das instituições do Consulado, do Senado e do povo, essa forma é a que admite, em seu interior, que os interesses opostos existentes na comunidade política possam se expressar e se tornar públicos” (ABREU, 2013, p. 70). Maquiavel enfatiza que a sangria institucional, por meio das leis, por exemplo, é a melhor forma de dar vazão aos conflitos e equilibrar os humores na república.

[...] se deve notar o que acima dissemos, a respeito da utilidade e da necessidade de as repúblicas, com suas leis, permitirem o desafogo da ira que o povo vota a um cidadão; porque, quando não há esses modos ordinários, recorre-se aos extraordinários; e sem dúvidas estes produzem efeitos muito piores que aqueles (MAQUIAVEL, 2007, p. 34).

Os efeitos piores, aos quais Maquiavel se refere, são as tiranias e desordens sociais que as repúblicas, por vezes, abrigam pela falta do equilíbrio e o equacionamento das forças políticas que as compõem. Por conta disso, reforça a importância das instituições como reguladoras dos atores sociais da vida republicana.

Visto como deve ser ordenado o conflito na república e o papel das instituições nesse ordenamento, partiremos, então, para outro ponto crucial na análise maquiavelina sobre o conflito da república: quais interesses devem nortear os conflitos?

Expusemos que o povo e os grandes possuem desejos; umori; predisposições diferentes no que se refere à sua concepção de mundo e envolvimento político na vida republicana. Entretanto, resta-nos saber se esses umori podem ser contemplados a partir de disposições individuais, ou se eles se organizam por meio de interesses comuns. 
Maquiavel (2007) pauta sua reflexão na virtude cívica, e isso pressupõe uma consciência que transcenda os interesses privados, buscando o bem comum, a virtude republicana. Nesse sentido, os conflitos chamados "sectários", baseados em interesses particulares (sètte), são prejudiciais à vida republicana. Ames, citando Maquiavel, destaca que é necessário distinguir a motivação dos conflitos, pois, quando não estão baseados em interesses republicanos, são perniciosos.

O que é preciso é introduzir uma clara distinção entre as divisões motivadas pelos conflitos, separando aquelas que prejudicam as repúblicas daquelas que as favorecem: "as prejudiciais são as que vêm acompanhadas por sètte e partidários; as proveitosas são as que se mantêm sem sètte e sem partidários” (AMES, 2014, p. 284).

Os umori opostos não podem ser organizados de qualquer maneira, pois, na análise maquiaveliana, isso é prejudicial à liberdade e à vida republicana. Os desejos devem ser canalizados para interesses que visem o bem comum republicano, de forma que os conflitos e embates dos grupos devem ser públicos, uma vez que, se migrarem para os interesses privados, a liberdade republicana fica comprometida, podendo incorrer em graves riscos, pois os humores "quando não se acordam na criação de uma lei em favor da liberdade, mas alguma das partes se opõe a favorecer alguém, logo surge a tirania" (MAQUIAVEL, 2007, p. 127).

Por esse motivo, Abreu destaca as relações públicas entre os grandes e o povo, como elemento fundamental para guardar a vida e liberdade na república.

\footnotetext{
Publicidade é uma ideia chave no pensamento republicano do autor e parece ser esse o fio que indica o alcance que pode ter o conflito para que ele seja considerado positivo. Isso porque, para Maquiavel, não é qualquer conflito, ou qualquer disputa entre o povo e os nobres que possa ser considerada positiva na vida de uma república. Os conflitos que não forem devidamente tornados públicos por meio das instituições são conflitos facciosos que, ao contrário de à grandeza, levam à ruína da república (ABREU, 2013, p. 73).
}

Entendemos que o conflito entre os grandes e o povo é essencial para a vida na república e que tal relação deve ser mediada por meio das instituições de maneira a viabilizar a vida política, prezando pela liberdade e continuidade do regime. Nessa dinâmica, as disposições que devem nortear os conflitos necessitam ser pautadas em valores cívicos, referentes a interesses públicos dos umori, não cedendo espaço para reivindicações e favorecimentos privados.

\section{O POVO COMO INTEGRANTE ATIVO NA REPÚBLICA MAQUIAVELIANA}


Para tratar do papel do povo na república maquiaveliana, é necessário, primeiramente, caracterizar quem é o povo na concepção do pensador florentino. A descrição de povo é constante nos escritos de Maquiavel; resta-nos saber quem é este elemento político que ganha tanta expressão em seu pensamento. Em diversas passagens de seus escritos, o autor menciona os termos povo e os grandes. Via de regra, esses são descritos por meio de seus umori, ou seja, seus desejos de não serem comandados e de comandar. Há pensadores como McCormick (2013) que defendem que a distinção entre esses grupos se dá por viés econômico. "Por 'povo', Maquiavel, geralmente, entende a plebe; isto é, os cidadãos romanos que não faziam parte da classe patrícia, excluídos os não cidadãos, como as mulheres, os escravos e os residentes estrangeiros" (MCCORMICK, 2013, p. 259). Entretanto, não parece ser essa a descrição de povo na obra maquiaveliana, uma vez que

\footnotetext{
Povo em Maquiavel pode significar também aquele que não se identifica com os desejos dos grandes de comandar. E nisso podem estar incluídas famílias ricas, nobres, assim como a pequena burguesia. $O$ que deve ficar claro é que Maquiavel não fez uma explicação convicta de quem é considerado povo e quem são os grandes, mas percebe-se pelo contexto de suas obras que ele não simplificou povo em pobres e grandes em ricos. A ênfase que Maquiavel pretendeu mostrar é a divisão de um corpo político (CASTEL, 2013, p. 8).
}

Entendemos que McCormick é um iminente estudioso das Ciências Políticas e que contribui para o debate profícuo sobre a temática, porém, não adotaremos suas premissas interpretativas no que concerne à análise do conceito de povo no pensamento maquiaveliano. Nossa posição coaduna com a de Ames (2011) e Castel (2013), de que o povo se caracteriza por seu humor: não ser dominado. Isto implica na afirmação de que o debate maquiaveliano extrapola as questões meramente econômicas, tendo como ponto de partida os desejos que motivam os diferentes grupos a participarem da vida política.

Quando entram em cena os papéis desempenhados pelas duas forças antagônicas que compõem a república, os comentadores maquiavelianos divergem frontalmente. Castel (2013) comenta, em seu artigo, que a corrente interpretativa à qual Quentin Skinner (2009) faz parte - denominada escola de Cambridge -, por exemplo, entende o desejo de liberdade do povo como algo passivo, não sendo uma ação política, propriamente dita, por esta fazer parte apenas de uma defensiva, e que, diante da segurança promovida por um governo forte, o desejo do povo estaria conformado. Skinner assim interpreta o papel do povo em Maquiavel: 
Maquiavel assume que "o povo pede apenas para não ser oprimido", e por isso mal se dá ao trabalho de lhe atribuir um papel minimamente relevante no drama da vida política. Insiste em que, enquanto o governante "não roubar à grande maioria a propriedade ou a honra", ela se "conservará satisfeita" e bastante maleável a suas vontades (SKINNER, 2009, p. 147).

$\mathrm{Na}$ linha contrária a essa interpretação, encontram-se estudiosos como Adverse, que entendem que a ação do povo, ainda que seja classificada como "negativa", não deixa de ser uma atividade que envolva a ação política militante, pressupondo seu ativismo, uma vez que tal desejo de liberdade prescreve uma ação, um modo de ser; logo, "esse ethos político da liberdade não pode ser compreendido apenas negativamente porque envolve um princípio da ação" (ADVERSE, 2007, p. 37). A disposição do povo ganha, então, conotações de "ativa" apontando para uma práxis de resistência, preponderante para manter o equilíbrio e movimentar a vida política republicana.

A passividade entendida por alguns comentadores não coaduna com a própria proposta de Maquiavel do povo como guardião da liberdade. Este não seria guardião por conta de sua posição passiva e conformista quando seu desejo de não ser oprimido é assegurado. Sua ação envolve uma prática não somente de resistência, como também de manutenção do equilíbrio dentro do regime republicano.

E sem dúvida, se considerarmos o objetivo dos nobres e o dos plebeus [ignobili], veremos naquele grande desejo de dominar e nestes somente o desejo de não ser dominados e, por conseguinte, maior vontade de viver livres, visto que podem ter menos esperança de usurpar a liberdade do que os grandes; de tal modo que, sendo os populares encarregados da guarda de uma liberdade, é razoável que tenham mais zelo e que não podendo eles mesmos apoderar-se dela não permitirão que outros se apoderem (MAQUIAVEL, 2007, p. 24).

A proposta de Maquiavel é que o povo seja o guardião da liberdade. Em sua exposição dos Discursos, evidencia essa posição pelos exemplos tirados da república romana em comparação à espartana. Sobretudo no capítulo quinto dessa obra, trata da responsabilidade do povo em manter a liberdade republicana. A questão que nos interpela é: por que o povo deve ser o guarda da liberdade?

A resposta ao questionamento levantado encontra-se na análise da disposição dos umori dentro da república. Uma vez que o desejo dos grandes é o de dominar, não poderiam, de acordo com a teoria maquiaveliana, ser eles os responsáveis para guarda da liberdade. "O bom senso aconselha a dar guarda de uma coisa àquele que tem menos desejo de dela se apoderar. Sendo assim, é ao povo que cabe a guarda da liberdade, uma vez que seu desejo é essencialmente o de não ser dominado" (ADVERSE, 2007, p. 40). 
Não é por falta de alternativa que o povo deve deter a guarda da liberdade, mas é, sobretudo, pela disposição de seu desejo (umori).

Além de ser o guarda da liberdade na república, o povo necessita de outros dois elementos preponderantes na manutenção da dinâmica republicana: ser fiel ao seu humor e não completar seu desejo de liberdade, mas não somente o povo necessita ser fiel à sua condição; isso é tarefa, também, dos grandes. Entretanto, como guardião da liberdade, o povo não pode ceder às paixões que permeiam a vida dos seres humanos e mudar de humor, passando a desejar aquilo que anseiam os grandes e completar seu desejo, gerando assim, desequilíbrio na república.

\footnotetext{
Para que o povo se mantenha na função de "guardião da liberdade", não basta que ele não mude de humor (que não passe do desejo de liberdade ao desejo de dominação), é preciso também que não realize na integralidade seu humor próprio (isto é, não complete seu desejo de liberdade, uma vez que a liberdade absoluta coincide com a anarquia plena, pois pressupõe a ausência de toda ordem fundada na coação e, assim, abre caminho à tirania) (AMES, 2009, p. 189).
}

Além disso, é necessário saber por qual liberdade o povo é responsável, ou ainda, guardião. O que implica essa liberdade?

Entendemos que a liberdade pela qual o povo é responsável por guardar possui amplos sentidos e pode ser identificada a partir de diversas variantes do pensamento político, jurídico e filosófico, mas é necessário compreender que, no nível institucional republicano, relaciona-se à disposição de autoridade para que, por intermédio daqueles que o representam, contribuia para o exercício de magistraturas, sendo que, nessa atividade, o povo não deverá almejar a dominação, sobrepujando os grandes. Adverse (2007, p. 43) explica como funcionavam as magistraturas na república romana e sua função na dinâmica política: “em Roma, a maior delas (ao menos a de maior prestígio) era o consulado, sendo um dos cônsules (e mais tarde os dois) eleito pela plebe e podendo ser ele próprio originado dela". Ainda, de acordo com o autor, além dessa função, cabia ao tribunato da plebe defender os interesses do povo, fazendo, assim, frente às possibilidades de uso excessivo do poder por parte do senado, de maneira que o tribunato detinha o poder de vetar as leis.

Depreende-se disso que ser guardião da liberdade relaciona-se com o direito de exercer o poder, ou por via representativa ou pelo exercício direto, de modo tal que o reconhecimento desse direito liga-se à participação ativa do povo na vida pública. Essa atividade expressa o papel fundamental do povo na república, pois não somente lhe é legado o papel de guarda da liberdade, mas, a partir da sua ação, contribuir para o 
fortalecimento e manutenção da vida política e equilíbrio entre as forças componentes do sistema.

Portanto, ao vislumbrar o conflito como forma da manutenção da liberdade republicana, Maquiavel estabelece as funções dos atores da vida pública como sendo o povo aquele que, por conta da disposição de seu desejo, também consegue fazer que as instituições e a vida republicana mantenham-se dinâmicas à medida que as demandas e novas conjunturas políticas vão surgindo no cenário.

É interessante notar que, para o autor, a liberdade não se dá pela paz e tranquilidade no sistema político, mas pelo conflito e pela disposição dos humores opostos que dão vazão às leis e demandas que movimentam o sistema político republicano. Tal proposição e ousadia de elaboração coloca Maquiavel, indubitavelmente, como um dos mais perspicazes e inovadores políticos modernos, uma vez que consegue analisar as situações políticas do passado, aplicando-as à sua realidade, fazendo conexão real dos fatos e dissecando-as à real matriz do pensamento político.

Essa posição inovadora e arrojada rende críticas ao pensamento maquiaveliano. Comentadores e críticos do pensamento político chegam a identificá-lo como defensor de um regime populista, como é o caso de McCormick (2013). Abreu, citando McCormick, comenta que "a valorização do conflito e a inclusão do povo no interior da comunidade política fez McCormick ver em Maquiavel um verdadeiro defensor de uma 'democracia populista" (ABREU, 2013, p. 71). O fato é que o pensador florentino analisa a política de forma a valorizar a atuação do povo por meio de uma prática política ativa por sua disposição e função dentro do sistema republicano.

É correto afirmar que Maquiavel sublinhou a importância da existência de mecanismos de participação popular, propondo denúncias públicas; defendendo a condenação das calúnias e reconhecendo os benefícios da atuação política coletiva, quando destaca que a participação coletiva do povo, pela disposição de seu humor em não querer ser dominado, contribui para a dinâmica republicana. Mas isso não significa que esse grupo tenha alguma vantagem sobre os grandes, ou seja, mais importante do que estes no processo. Para Maquiavel o importante é o conjunto:

[...] nota-se em primeiro lugar que em Roma se incorreu no inconveniente de criar uma tirania pelas mesmas razões por que nasce a maior parte das tiranias nas cidades: pelo demasiado desejo do povo de ser livre e pelo demasiado desejo dos nobres de comandar. E, quando não se acordam na criação de uma lei em favor da liberdade, mas alguma das partes se opõe a favorecer alguém, logo surge a tirania (MAQUIAVEL, 2007, p. 127). 
Se o importante, para Maquiavel, é o conjunto, por que destacar o papel do povo? O papel do povo é destacado justamente por este fazer parte do conflito de forma ativa, por meio de uma participação na vida pública republicana. Chama-nos à atenção a perspectiva singular de atribuir a guarda da liberdade, não ao grupo dominante do processo político, e, sim, ao dominado, conferindo a ele não somente o papel de guardião, mas também a responsabilidade de contribuir na dinâmica política por meio da manifestação de seus umori.

Ainda assim, é importante destacar que Maquiavel não defendeu a supremacia de um grupo sobre outro, caracterizando a república como popular ou burguesa, mas sinalizou a disputa entre os humores dos atores políticos como indispensável para que haja liberdade republicana.

O que precisa ser destacado é que seu pensamento se constitui como inovador quando atribui ao povo um papel ativo no jogo político, diferentemente da tradição histórica que o antecedera, pois essa o tinha, simplesmente, como uma classe que compunha o cenário político, mas não lhe atribuía nenhuma função ou papel destacado. Não somente pelo fato de guardar a liberdade é que o povo merece destaque no pensamento maquiaveliano; antes, procurou-se salientar que sua importância encontra-se no fato de este ser componente ativo da vida republicana, contribuindo, assim, para a manutenção da liberdade no regime.

\section{CONCLUSÃO}

É interessante notar que Maquiavel concebe a república como um espaço democrático participativo e organizado, dando vazão à participação dos diferentes grupos que a compõem. Tal posição instiga a reflexão, sobretudo, em tempos em que alguns movimentos sociais, que representam os "humores" do povo, são criminalizados e deixados à margem da sociedade brasileira e latino-americana.

Maquiavel é perspicaz ao perceber que o povo exerce um papel de suma importância em uma república democrática e, por isso, sinaliza para ele o equilíbrio do sistema e a manutenção da liberdade. As problematizações lançadas pelo autor abrem margem para questionamentos, quando, por exemplo, um humor se sobressai em relação a outro, ou ainda, um setor ou poder sobrepõe-se aos demais, dando vazão a tiranias e desequilíbrios democráticos. 
O conflito como promotor da liberdade na república maquiaveliana Luis Fernando de Carvalho Sousa

Tais apontamentos se mostram atuais, sobretudo para se pensar a realidade latinoamericana que viveu sob ditaduras, espoliações estrangeiras e busca corrigir o curso de sua história democrática por meio do amadurecimento de seus regimes. O elemento povo pode, sem dúvidas, ajudar a amadurecer a democracia pelos embates com as elites, sinalizando para a liberdade republicana.

\section{REFERÊNCIAS}

ABREU, Maria Aparecida Azevedo. A densidade conflitiva da república nos Discorsi de Maquiavel. Revista Brasileira de Ciência Política, Brasília, n. 12, p. 67-97, 2013. Disponível $\quad \mathrm{em}: \quad<$ http://www.scielo.br/scielo.php?script $=$ sci $\operatorname{arttext\& pid=S0103-}$ 33522013000300004>. Acesso em: 20 nov. 2015.

ADVERSE, Helton. Maquiavel, a república e o desejo de liberdade. Trans/Form/Ação, São Paulo, v. 30, n. 2, p. 33-52, 2007. Disponível em: < http://www.scielo.br/pdf/trans/v30n2/a04v30n2.pdf>. Acesso em: 10 out. 2015.

AMES, José Luiz. Lei e violência ou legitimação política em Maquiavel. Trans/Form/Ação, São Paulo, v. 34, n. 1, p. 21-42, 2011. Disponível em: < http://www.scielo.br/pdf/trans/v34n1/a03v34n1 >. Acesso em: 15 jan. 2016.

Liberdade e conflito - o confronto dos desejos como fundamental na ideia de liberdade em Maquiavel. Kriterion: Revista de Filosofia, Belo Horizonte, n. 119, p. 179196, 2009. Disponível em: < $\underline{\text { http://dx.doi.org/10.1590/S0100-512X2009000100009>. }}$. Acesso em: 3 fev. 2016.

Transformações no significado de conflito na "História de Florença"de Maquiavel. Kriterion: Revista de Filosofia, Belo Horizonte, n. 129,p. 265-286, 2014. Disponível em: $\quad<$ http://www.scielo.br/scielo.php?script=sci arttext\&pid=S0100$\underline{12 X 2014000100015}>$. Acesso em: 3 fev. 2016.

CASTEL, Karen Elena Costa Dal. O povo em Maquiavel como detentor da guarda da liberdade. SIMPÓSIO DE PÓS-GRADUAÇÃO EM CIÊNCIA POLÍTICA, 1., 2013, São Carlos. Anais eletrônicos... São Carlos: Universidade Federal de São Carlos, 2013. Disponível em: <http://www.semacip.ufscar.br/wp-content/uploads/2014/12/O-Povoem-Maquiavel-como-Detentor-da-Guarda-da-Liberdade.pdf>. Acesso em: 15 dez. 2015.

MAQUIAVEL, Nicolau. O Príncipe. São Paulo: Martins Fontes, 2010.

2007.

Discursos sobre a primeira década de Tito Lívio. São Paulo: Martins Fontes,

MCCORMICK, John P. Democracia maquiaveliana: controlando as elites com um populismo feroz. Revista Brasileira de Ciência Política, Brasília, n. 12, p. 253-298, 2013. Disponível em: < http://dx.doi.org/10.1590/S0103-33522013000300010>. Acesso em: 25 jan. 2016. 
RAMOS, Silvana de Souza. Maquiavel e a política do desejo. Cadernos de Ética e Filosofia Política, São Paulo, n. 20, 2010. Disponível em: <http://www.revistas.usp.br/cefp/article/viewFile/85746/88508>. Acesso em: 28 set. 2015.

SILVA, Ricardo. Maquiavel e o conceito de liberdade em três vertentes do novo republicanismo. Revista Brasileira de Ciências Sociais, Brasília, v. 25, n. 72, p. 37-58, 2010. Disponível em: <http://www.scielo.br/pdf/rbcsoc/v25n72/v25n72a04.pdf>. Acesso em: 15 out. 2015.

SKINNER, Quentin. As fundações do pensamento político moderno. São Paulo: Companhia das Letras, 2009.

Recebido para avaliação em 06/07/2016 Aceito para publicação em 14/03/2017 